\title{
MANAGEMENT OF VARIOUS PATIENTS IN DAY CARE TRANSFUSION CENTER AT TRANSFUSION MEDICINE DEPARTMENT OF DHAKA MEDICAL COLLEGE HOSPITAL, DHAKA - ANNUAL AUDIT OF 2013
}

\author{
KARIM S ${ }^{1}$, HOQUE MM ${ }^{2}, \mathrm{HOQUE} \mathrm{E}^{3}, \mathrm{DEY} \mathrm{SR}^{4}, \mathrm{BEGUM} \mathrm{HA}^{4}$
}

\begin{abstract}
Objective: This study was carried out to improve day care transfusion facilities day by day as well as it is very time consuming and cost benefit both for patient and hospital authority, also government.

Methods: According to instruction of the attending physicians, patients who were coming for day care transfusion all were recorded in prescribed data like name, age, sex, disease, number of transfusion, transfusion reaction, etc. After proper cross matching and screening of donated blood, transfusion should be started, and monitor the patient every 15 minutes. If there is any transfusion reaction during or after transfusion, it should be noted and managed immediately. During this study, data was collected from record registered.

Results: In this study, we found 742 patients were attended at Day Care Transfusion Center at DMCH, Dhaka, Bangladesh,in 2013. Among total patients male and female were 432 (58.23\%)and 310 (41.77\%) respectively. Age ranges of patients were 10-40 years 120 (16.17\%) and 41-80 years 622 (83.82\%).Among total patients, 548 (73.85\%) were malignant. Other disease were aplastic anaemia, thalassaemia, myeloproliferative disease, Chronic kidney disease, Dysfunctional uterine bleeding, severe anemia due to unknown cause were 24(3.23\%), 23(3.099\%),50(6.73\%), 43(5.79\%),28(3.77\%), 16 (2.15\%) respectively
\end{abstract}

Key words: Day care, transfusion.

J Dhaka Med Coll. 2014; 23(2) : 191-193.

\section{Introduction}

The Day Care Transfusion was started on 2006 in the Transfusion Medicine department, in Dhaka Medical College Hospital (DMCH), Dhaka, Bangladesh. Day Care Transfusion Centers play an important role of providing blood transfusions and monitoring the patient during transfusion. In day care center patient does not require admission into the hospital rather can receive blood as an outdoor patient. The patients would have to directly report at the daycare centre for their specified procedures and get discharged on the same day after going through the treatment. This will save the patients a whole lot of trouble and inconvenience as they would get treatment and return home on the same day without being hospitalized.

About ten to twelve patients are getting transfusion service per day in this Day Care centre. Anemia in cancer patients can be a combined outcome caused by myelosuppressive chemotherapy, and possible cancer-related causes such as bleeding blood cell, destruction), hereditary disease, kidney dysfunction, nutritional deficiencies and/or anemia of chronic disease $\mathrm{e}^{1,2,3}$. Myelosuppressive therapy can cause a tendency to bleed easily, leading

1. Dr. Shanaz Karim, Assistant Professor, Department of Transfusion Medicine, Dhaka Medical College Hospital, Dhaka.

2 Dr. Md. Mazharul Hoque, Associate Professor, Department of Transfusion Medicine, Dhaka Medical College Hospital, Dhaka.

3. Dr. Ehteshamul Hoque, Associate Professor, Department of Oncology, Anower Khan Modern Medical College Hospital, Dhaka.

4. Dr. Sudip Ranjan Deb, Assistant Professor, Department of Medicine, Dhaka Medical College, Dhaka

5. Dr. Husne Ara Begum, Professor and Head, Department of Transfusion Medicine, Dhaka Medical College Hospital, Dhaka.

Correspondence : Dr. Shanaz Karim, Assistant Professor, Department of Transfusion Medicine, Dhaka Medical College Hospital, Dhaka. 
to anemia. Medications that kill rapidly dividing cells or blood cells can reduce the number of platelets in the blood, which can result in bruises and bleeding. ${ }^{4,5}$.

\section{Methods}

According to instruction of the attending physicians patients who were come for day care transfusion were recorded in prescribed data like name, age, sex, disease, number of transfusion, transfusion reaction ,etc.. After proper cross matching and screening of donated blood, transfusion should be started, and monitor the patient every 15 minutes. If there is any adverse transfusion reaction during or after transfusion should be observed accurately, documented and evaluated and managed immediately. During this study, data were collected from hospital records.

\section{Results}

In this study, we found 742 patients were attended at Day Care Transfusion Center at $\mathrm{DMCH}$ on 2013. Among total patients male and female were $432(58.23 \%)$ and 310 (41.77\%) respectively. Age ranges of patients were 10 40 years $120(16.17 \%)$ and $41-80$ years 622 (83.82\%) Among total patients, 548 (73.85\%) were malignant. Other disease were Aplastic anaemia, thalassaemia, myeloproliferative disease, chronic kidney disease, dysfunctional uterine bleeding, severe anaemia due to unknown cause were 24(3.23\%), 23(3.099\%), $50(6.73 \%), 43$ (5.79\%), 28 (3.77\%), 16 $(2.15 \%)$ respectively. In the present study, blood group of attending patient at day care centre were $\mathrm{O}$ positive $305(41.10 \%)$, B positive 197(26.97\%),Apositive167(22.50\%), AB positive 49 (6.60\%). Rh negative blood group O, A, B, AB were9 (1.21\%),3(.404\%), 10(1.34\%),2(0.269\%) respectively.

The results are showing in following tables:

Table-I

Age distribution of patients ( $n=742$ )

\begin{tabular}{lcc}
\hline Age & Number & $\%$ \\
\hline $10-40$ Year & 120 & $16.17 \%$ \\
$41-80$ Year & 622 & $83.82 \%$ \\
\hline
\end{tabular}

Table-II

Distribution of sex of patients ( $n=742)$

\begin{tabular}{lcc}
\hline Sex & Number & $\%$ \\
\hline Male & 432 & $58.23 \%$ \\
Female & 310 & $41.77 \%$ \\
\hline
\end{tabular}

Table-III

Distribution of blood group among patients $(n=742)$

\begin{tabular}{lcc}
\hline Total Patient & Number & $\%$ \\
\hline O positive & 305 & 41.10 \\
B positive & 197 & 26.54 \\
A positive & 167 & 22.50 \\
AB positive & 49 & 6.60 \\
O negative & 09 & 1.21 \\
A negative & 03 & .404 \\
B negative & 10 & 1.34 \\
AB negative & 02 & .269 \\
\hline
\end{tabular}

Table IV

Various diseases among the study cases $(n=742)$

\begin{tabular}{lcc}
\hline Type of diseases & Number & $(\%)$ \\
\hline Malignancy & 548 & 73.85 \\
Aplastic anemia & 24 & 3.23 \\
Thalasemia & 23 & 3.099 \\
Myeloproliferative disease & 50 & 6.73 \\
Chronic kidney disease & 43 & 5.79 \\
Dysfunctional uterine bleeding & 28 & 3.77 \\
severe anemia due to & 16 & 2.15 \\
unknown cause & & \\
\hline
\end{tabular}

Table-V

Use of whole blood and blood component $(n=742)$

\begin{tabular}{lcc}
\hline Blood / component & Number & $\%$ \\
\hline Whole blood & 617 & $83.15 \%$ \\
Red cell concentrate & 125 & $16.84 \%$ \\
\hline
\end{tabular}

\section{Discussion}

In this study, we found 742 patients attended the Day Care Transfusion Center at DMCH on 2013. Among total patients male and female were 432 $(58.23 \%)$ and $310(41.77 \%)$ respectively. Age ranges of patients were $10-40$ years $120(16.17 \%)$ and $41-80$ years $622(83.82 \%)$ 
Among total patients, $518(73.85 \%)$ were malignant. Other disease were Aplastic anaemia, Thallasimia, Myeloproliferative disease, Chronic kidney disease, Dysfunctional uterine bleeding, severe anemia due to unknown cause. were $24(3.23 \%, 23(3.099 \%)$, $50(6.73 \%) \quad 43(5.79 \%) .28(3.77 \%) 16 \quad,(2.15 \%)$ respectively. In present study blood group of attending patient at day care centre were $\mathrm{O}$ positive $305(41.10 \%)$,B positive $197(26.97 \%)$ ,Apositive 167(22.50\%) AB positive 49 (6.60\%). $\mathrm{Rh}$ negative blood group $\mathrm{O}, \mathrm{A}, \mathrm{B}, \mathrm{AB}$ were 09 (1.21\%), 03(.404\%), 10(1.34\%),02(.269\%) respectively.

Out of 742 patients 518 patients were malignant cases. The malignant patients usually attending more in number than other patients such as aplastic anemia, thalassaemia, myeloproliferative disease, severe anaemia due to unknown cause, etc. Anemia of chronic disease (ACD) is common in patients with can with cancer. ${ }^{6}$ It is characterized by erythroid hypoplasia, inadequate serum erythropoietin (EPO) levels in response to the anemia, and poor iron reutilization by the bone marrow. 7,8 Anemia in cancer patients is often exacerbated by myelosuppressive chemotherapy and may also be aggravated by radiation therapy. Cancer patients may experience such severe anemia that red blood cell (RBC) transfusions are required for symptomatic palliation. In particular, adverse transfusion reactions should be observed accurately, documented and evaluated. Subsequently this may serve as a strong rationale to improve the blood transfusion system.

\section{Conclusion}

Many patients are dependent on blood transfusion for survival. Now a days the daycare transfusion facilities are becoming popular as they are very convenient option. Day care patient services enables health care providers to avoid costly patient hospitalization for transfusion, administration offering blood component transfusion on an out patients basis. In particular, adverse transfusion reactions should be observed accurately, documented and evaluated. Subsequently this may serve as a strong rationale to improve the blood transfusion system. In the end this will help to adequately motivate the professionals to support the development and introduction of formal transfusion policies and guidelines, and to adequately adhere to the latter.

\section{References}

1. Groopman JE, Itri LM.Chemotherapy-induced anemia in adults: incidence and treatment. J Natl Cancer Inst 1999;91(19): 1616-34.

2. Henry DH. The role of intravenous iron in cancerrelated anemia.Oncology 2006; 20(Supp1 6): 21-4.

3. Jump up Rodgers GM, Becker PS, Bennett CL, et al.Cancer- and chemotherapy-induced anemia. J Natl ComprCancNetw2008; 6(6): 536-64.

4. Vadhan-Raj S. Management of chemotherapyinduced thrombocytopenia: current status of thrombopoietic agents. Semin.Hematol 2009;46 (1 Suppl 2): S26-32.

5. Sekhon SS, Roy V. Thrombocytopenia in adults: A practical approach to evaluation and management. South Med J 2006;99 (5): 491-8.

6. Skillings JR, Sridhar FG, Wong C, et al. The frequency of red cell transfusion for anemia in patients receiving chemotherapy: a retrospective cohort study. Am J ClinOncol1993;16:22-5.

7. Johnson R, Roodman G. Hematologic manifestations of malignancy. DM1990;35: 716-68.

8. Means RT, Krantz SB. Progress in understanding the pathogenesis of the anemia of chronic disease. Blood 1992;80:1639-47. 